\title{
Effect of preservation on dinoflagellate and diatom cell volume and consequences for carbon biomass predictions
}

\author{
Susanne Menden-Deuer*, Evelyn J. Lessard, Jessi Satterberg \\ School of Oceanography, University of Washington, Box 357940, Seattle, Washington 98195, USA
}

\begin{abstract}
Plankton biomass estimates are often made using cell size measurements from samples preserved with fixatives such as Lugol's or glutaraldehyde. However, preservation of plankton samples can introduce artifacts to species abundance and cell volume estimates. The goal of this study was to quantify the extent of fixation-induced cell volume change in 18 species of dinoflagellates and 8 species of diatoms in order to provide correction factors to improve biomass estimates. Highly variable and species-specific cell volume changes were found with respect to cell covering, fixative type and strength, time of storage and analysis method (light vs epifluorescence microscopy). Both swelling and shrinking were observed with both fixatives in dinoflagellates and diatoms. Dinoflagellate cell volume changes ranged from over $60 \%$ shrinkage to $30 \%$ swelling. Cell volume of some diatom species shrank over $30 \%$ and swelled almost $30 \%$. These results contradict the common assumption that diatoms are not affected by preservation due to their silica frustule. The observed cell volume changes for both dinoflagellates and diatoms differed from those reported for ciliates and other flagellates. Therefore, application of previously reported correction factors would lead to inaccurate estimates of biovolume and thus carbon biomass. Fixation caused significant changes in biomass predictions of individual dinoflagellate and diatom species. However, biomass estimates for samples containing several species were not significantly different whether based on live or fixed cell volumes.
\end{abstract}

KEY WORDS: Preservation · Fixation · Artifacts $\cdot$ Cell volume $\cdot$ Biomass $\cdot$ Diatom $\cdot$ Dinoflagellate Lugol's solution · Glutaraldehyde

Resale or republication not permitted without written consent of the publisher

\section{INTRODUCTION}

Accurate biomass estimates are essential to determine the quantitative role of dinoflagellates and diatoms in microbial food webs. Both dinoflagellates and diatoms can be significant primary producers and the accuracy of biomass measurements has important ramifications for estimates of global carbon (C) and silica biogeochemistry. Additionally, many dinoflagellate species are heterotrophic, and accurate biomass estimates are needed to assess their trophic significance. Estimates of $\mathrm{C}$ biomass for planktonic organisms are usually made by converting cell volume to cellular $\mathrm{C}$ content using empirical or theoretical $\mathrm{C}$ to volume

*E-mail: smenden@ocean.washington.edu ratios. C to volume relationships have been established for a number of planktonic protist groups. Some conversions are based on cell volumes of live specimens (Parsons et al. 1961, Montagnes et al. 1994, MendenDeuer \& Lessard 2000), whereas others are based on cell volumes of fixed specimens (Mullin et al. 1966, Strathmann 1967, Verity \& Langdon 1984, Verity et al. 1992). Most cell size measurements of plankton samples have been made based on fixed plankton samples; however, $\mathrm{C}$ to volume relationships based on live cells have often been used to estimate plankton biomass from fixed samples. Failure to take fixation-induced cell volume changes into account could lead to inaccurate estimates of plankton biomass.

Plankton samples collected in the field are often treated with fixatives to preserve organisms for future 
taxonomic identification and quantification. Widely used fixatives include Lugol's iodine and Bouin's solutions, glutaraldehyde and formaldehyde. Each of these fixatives has been shown to introduce artifacts, including failure to preserve certain taxa (e.g. through dissolution of $\mathrm{CaCO}_{3}$ ), reduction in the abundance of particular taxa and changes in cell size (e.g. Leakey et al. 1994, Stoecker et al. 1994). Preservation-induced artifacts have long been recognized as potentially significant factors in introducing bias to the analysis of plankton samples (Throndsen 1978, Booth 1987, Stoecker et al. 1994). These artifacts have been studied extensively in ciliates (e.g. Leakey et al. 1994, Stoecker et al. 1994) and in groups of phylogenetically diverse phytoplankton, including some dinoflagellate and diatom species (Booth 1987, Verity et al. 1993, Montagnes et al. 1994). However, no study has systematically investigated the importance of fixation-induced cell size changes in dinoflagellates and diatoms. The goal of this study was to determine whether fixation-induced cell volume changes affect plankton cell volume measurements in a predictable fashion, such that correction factors might be applied to improve C biomass estimates.

To address these issues, the relationship between cell volume of live and fixed dinoflagellates and diatoms was examined, and the potential bias of fixation on cellular C content estimates was quantified. We hypothesized that: (1) different types of fixatives have different effects on cell volume; (2) cell volume changes consistently during storage; (3) higher concentrations of the same fixative alter cell volume to a greater extent; (4) groups of species with different types of cell covering (i.e. silica frustule in diatoms, polysaccharide plates in thecate and membrane in athecate dinoflagellates) respond differently to fixation; and (5) filtration of fixed samples for analysis with epifluorescence microscopy affects cell volume differently than settling fixed samples for light microscopy.

\section{MATERIALS AND METHODS}

Culturing conditions. Diatoms and phototrophic dinoflagellates were cultured at $18^{\circ} \mathrm{C}$ in $\mathrm{F} / 2$ medium (Guillard 1975) in 500 to $1000 \mathrm{ml}$ polycarbonate bottles. Cultures were grown on 16:8 h light:dark cycle, at $100 \mu \mathrm{mol}$ photons $\mathrm{m}^{-2} \mathrm{~s}^{-1}$ provided by cool and warm white lights. Cultures were transferred every $12 \mathrm{~d}$ to maintain exponential growth. One species, Ceratium fusus, failed to grow at $18^{\circ} \mathrm{C}$ in standing flasks and was maintained at $12^{\circ} \mathrm{C}$ on a plankton wheel at $1 \mathrm{rpm}$ (all other conditions as above). The heterotrophic dinoflagellates, Protoperidinium spp., were fed the diatom Ditylum brightwellii and maintained at $12^{\circ} \mathrm{C}$ in $\mathrm{F} / 2$ medium at $30 \mu \mathrm{mol}$ photons $\mathrm{m}^{-2} \mathrm{~s}^{-1}$ on a plankton wheel at $1 \mathrm{rpm}$. Oxyrrhis marina and Bernardinium sp. were fed the cryptophyte Rhodomonas lens and maintained at $18^{\circ} \mathrm{C}$ in $250 \mathrm{ml}$ Erlenmeyer flasks at $30 \mu \mathrm{mol}$ photons $\mathrm{m}^{-2} \mathrm{~s}^{-1}$. All species and their origin are listed in Table 1.
Table 1. Culture collection or origin of wild-type isolate source of dinoflagellate and diatom species analyzed in this study

\begin{tabular}{|c|c|}
\hline Species & Source \\
\hline \multicolumn{2}{|l|}{ Diatoms } \\
\hline Chaetoceros didymus Ehrenberg & Puget Sound, WA \\
\hline Coscinodiscus sp. Kützing & Puget Sound, WA \\
\hline Ditylum brightwellii (West) Grunow & $\mathrm{CCMP}^{1} 358$ \\
\hline Leptocylindrus danicus Cleve & CCMP 470 \\
\hline Lithodesmium undulatum Ehrenberg & CCMP 472 \\
\hline Stephanopyxis cf. palmeriana (Graeville) Grunow & Puget Sound, WA \\
\hline Thalassiosira rotula Meunier & Puget Sound, WA \\
\hline Thalassiosira sp. Cleve & CCMP 1057 \\
\hline \multicolumn{2}{|l|}{ Dinoflagellates (athecate) } \\
\hline Amphidinium asymmetricum Kofoid \& Swezy & $\mathrm{NEPCC}^{2} 67$ \\
\hline Amphidinium carterae Hulburt & UW Botany UTEX LB 1002 \\
\hline Amphidinium operculatum Kofoid \& Swezy & unknown \\
\hline Bernardinium sp. & Georges Bank \\
\hline Gymnodinium sanguineum Hirasaka & CCMP 1740 \\
\hline Gymnodinium simplex (Lohmann) Kofoid \& Swezy & unknown \\
\hline Oxyrrhis marina Dujardin & Norway \\
\hline \multicolumn{2}{|l|}{ Dinoflagellates (thecate) } \\
\hline Alexandrium catenella (Whedon \& Kofoid) Balech & East Sound, Orcas Island, WA \\
\hline Ceratium furca (Ehrenberg) Claparède \& Lachmann & Puget Sound, WA \\
\hline Ceratium fusus (Ehrenberg) Dujardin & Puget Sound, WA \\
\hline Ceratocorys horrida Stein & UW Botany UTEX LB 2499 \\
\hline Glenodinium foliaceum Stein & UW Botany UTEX LB 1688 \\
\hline Glenodinium sp. & UW Botany UTEX LB 1625 \\
\hline Prorocentrum micans ${ }^{3}$ (a) Ehrenberg & unknown \\
\hline Prorocentrum micans (b) Ehrenberg & NEPCC 33 \\
\hline Protoperidinium conicum (Gran) Balech & Puget Sound, WA \\
\hline Protoperidinium depressum (Bailey) Balech & Puget Sound, WA \\
\hline Protoperidinium pellucidum (Bergh) Schütt & Puget Sound, WA \\
\hline Scrippsiella trochoidea (Stein) Loeblich III & NEPCC 15 \\
\hline
\end{tabular}


Sampling and fixation treatments. All species were harvested during the exponential growth phase. The effect of 2 widely used fixatives on cell volume was determined using acid Lugol's iodine solution (hereafter Lugol's; Throndsen 1978) and glutaraldehyde on 10 dinoflagellate and 8 diatom species measured using light microscopy and settled samples (Table 2). Typically, the final concentration of glutaraldehyde used ranges between 0.5 and $2 \%$. Therefore, a concentration of $1 \%$ glutaraldehyde was chosen for this analysis. In contrast, Lugol's final concentrations are more variable and subjective (e.g. tea or whiskey colored as described by Montagnes et al. 1994); Lugol's was used at a final concentration of $2 \%$. The samples were measured within $1 \mathrm{wk}$ of fixation, except for species included in the time course experiment (below) where the longest stored samples were included.

To estimate cell volume changes during storage time, 4 species of dinoflagellates (Ceratium fusus, Gymnodinium sanguineum, G. simplex, Scrippsiella trochoidea) and 3 diatom species (Coscinodiscus sp., Ditylum brightwellii, Thalassiosira sp.) were fixed with $2 \%$ Lugol's or $1 \%$ glutaraldehyde, stored in glass scintillation vials in the dark at $4^{\circ} \mathrm{C}$ and measured repeatedly over a period of up to $8 \mathrm{mo}$.

The effect of Lugol's concentration on cell volume was examined in 3 dinoflagellate species (Amphidinium carterae, Ceratium fusus, Gymnodinium sanguineum) and 3 diatom species (Coscinodiscus sp., Ditylum brightwellii, Thalassiosira sp.). These species were chosen because they represent a wide range of cell sizes within each group. Each species was fixed with 0.5, 2 and $10 \%$ Lugol's, reflecting the range of working concentrations (Montagnes et al. 1994). Cell volumes were measured after $1 \mathrm{~d}$ of fixation in dinoflagellates and after $1 \mathrm{wk}$ in diatoms.

The influence of glutaraldehyde fixation in combination with filtration on cell volume was examined for 14 athecate and thecate dinoflagellate species (Table 3). These samples were fixed to a final concentration of $1 \%$ glutaraldehyde, stained with $5 \mu \mathrm{g} \mathrm{ml}^{-1}$ final concentration DAPI for $3 \mathrm{~min}$, drawn onto $0.2 \mu \mathrm{m}$ black polycarbonate filters on top of pre-wetted

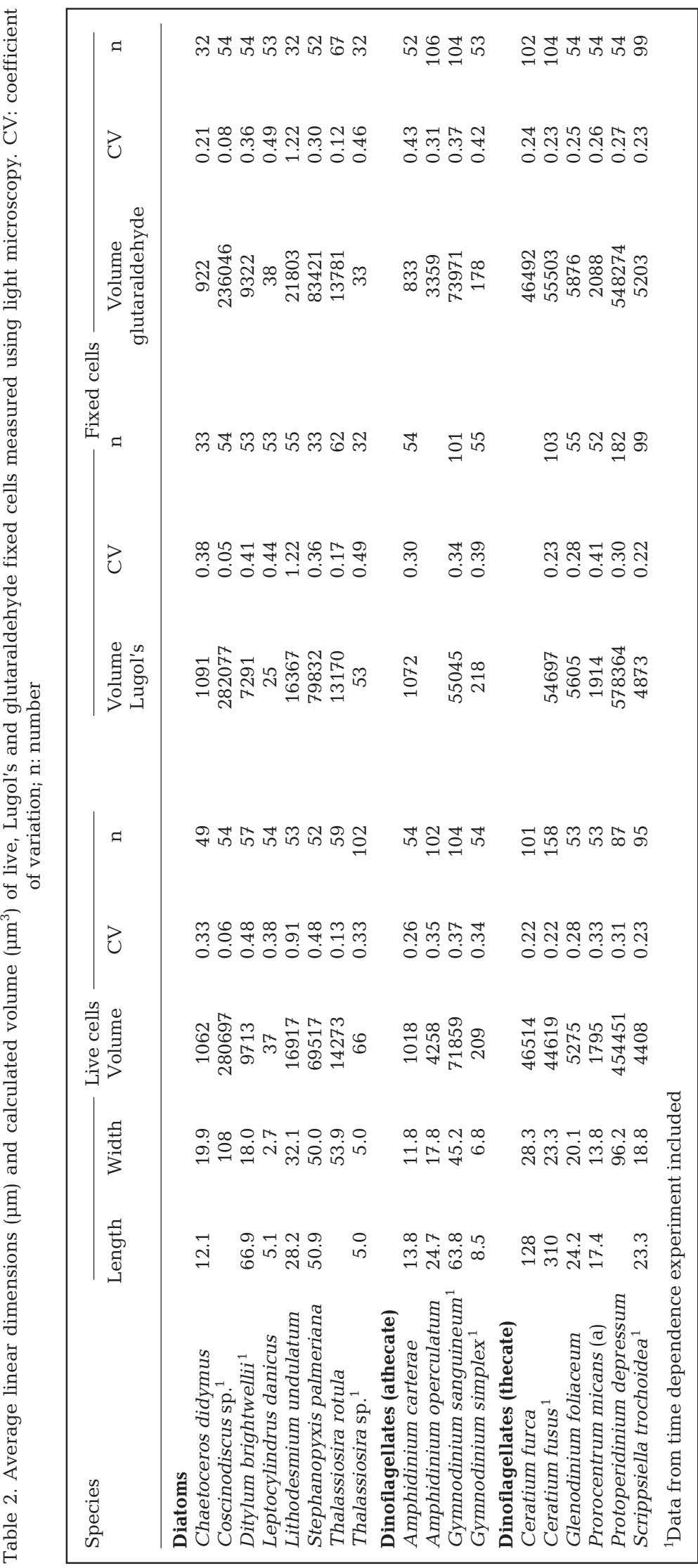




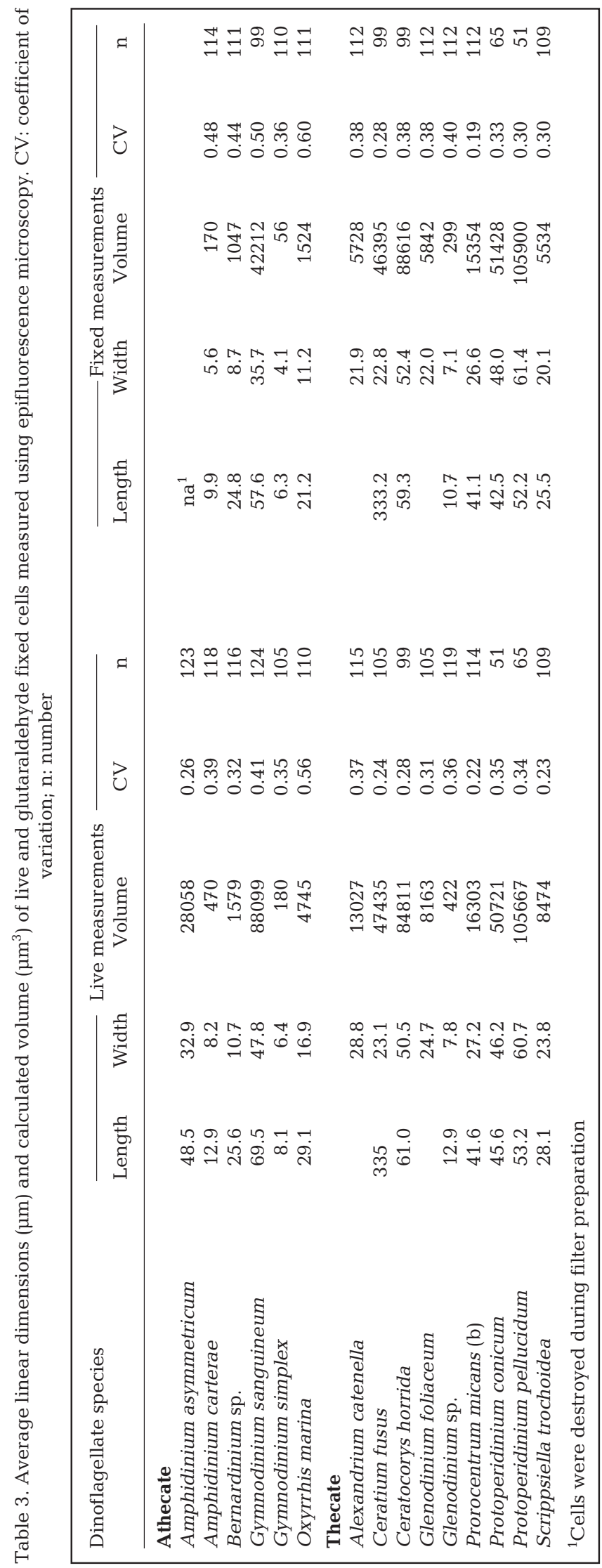

$0.8 \mu \mathrm{m}$ nylon backing filters (Poretics) and frozen for a period of 10 to 12 wk before examination (Lessard \& Murrell 1996). In all treatments, sample volume was $10 \mathrm{ml}$ and the fixative was added to the sample, rather than adding the sample to the fixative; this method may have caused some cells to experience less than the target fixative concentration.

Microscopic analysis. All live cell dimensions were measured in a settling chamber using transmitted light and magnification between 200 to $400 \times$. Live samples were examined when sufficient numbers of cells had settled, usually within $30 \mathrm{~min}$ to $2 \mathrm{~h}$. If necessary, live cells were immobilized by adding nickel sulfate $(0.003 \%$ final concentration). Nickel sulfate did not appear to alter cell shape or size during the time of measurement; however, no quantitative comparisons were possible, since live cells could not be measured without immobilization with this method. Lugol's and glutaraldehyde preserved cells were measured after settling for a minimum of $3 \mathrm{~h}$. The glutaraldehyde preserved, filtered samples were examined with epifluorescence microscopy with blue light and/or UV excitation. No preserved measurements could be obtained for Amphidinium asymmetricum, an athecate dinoflagellate, because this species either lysed or was unrecognizable after fixation. A Zeiss Axiovert microscope equipped with a digitizer pad and Microbiota software (Roff \& Hopcroft 1986) was used for both transmitted light and epifluorescence measurements. The precision of microscopic measurements using the digitizer was determined to be $\pm 0.5 \mu \mathrm{m}$ for length measurements between 10 and $100 \mu \mathrm{m}$. For each sample, 30 to 150 individual cells were measured (Tables 2 \& 3). Linear measurements were converted to cell volume using geometric formulae and the considerations discussed in MendenDeuer \& Lessard (2000).

Data analysis. The results for the statistical analysis are reported for cell volumes only. However, the results do not differ whether based on the linear dimensions or volume. To normalize the data, individual volume measurements were $\log _{10}$ transformed. Comparisons involving 1 or more factors were made using 1- or 2-factor ANOVA. In order to take species to species variability into account when examining the significance of the type of cell covering for the observed volume changes, species were included as a nested factor in the ANOVA. Identification of significantly different groups were made using appropriate posthoc tests (e.g. Student-Newman-Keuls). The nonparametric equivalent, ANOVA on ranks/KruskalWallis, was used when data were not normally distributed or violated the assumption of equal variance. Contrasts of cell volume averages before and after fixation were made using either a paired $t$-test or 
a Wilcoxon signed rank test, the latter in cases where data were not normally distributed. Quantitative relationships between 2 parameters were described through linear regression analysis (Model I). Differences were judged non-significant when $p \geq 0.05$. To facilitate between species comparisons, relative cell volume changes were determined by computing the relative difference $(\Delta)$ between live $(L V)$ and fixed $(F V)$ volume: $\Delta=(F V-L V) / L V$. Generally, it is recommended to subject such fractions to an arcsine transformation, to avoid non-normal data distribution (Zar 1996). Thus, we first confirmed that the fraction data were normally distributed before proceeding with the data analysis.

\section{RESULTS}

\section{Fixative and cell covering type}

With the exception of Lithodesmium undulatum, the coefficient of variation (CV) of live and fixed cell volumes (Table 2) compare well to published CV values (Putt \& Stoecker 1989, Verity et al. 1992, MendenDeuer \& Lessard 2000). Fixation with either Lugol's or glutaraldehyde and measurement with a light microscope resulted in highly variable cell volumes with up to $50 \%$ shrinkage and almost $30 \%$ swelling (Table 2, Fig. 1). Some species showed no change in cell volume. A 2-factor ANOVA was used to examine whether the type of fixative and/or the type of cell covering significantly affected observed cell volume changes. The importance of the cell covering was tested by grouping different species with the same cell covering. However, these species are characterized by more differences than cell covering alone. Therefore, to take species to species differences within each group into account, the different species were nested as a factor within the cell covering factor. Even when considering among species differences, only the type of cell covering significantly influenced cell volume changes $(p=$ 0.015). Therefore, data for both types of fixative were combined and fixation-induced cell volume changes were examined in the 3 groups separately. As a group, thecate dinoflagellate cell volumes increased significantly $(p=0.0004)$ upon fixation. The average increase in cell volume was $16 \%$ and ranged from no volume change to $30 \%$ swelling. The average athecate dinoflagellate volume was $9 \%$ lower after fixation and the average diatom volume was $7 \%$ lower. However, the average difference between live and fixed volumes was not statistically significant for either group. Nonetheless, individual species' live and fixed cell volumes differed considerably. In athecate dinoflagellates, cell volume changes ranged from $23 \%$ shrinkage

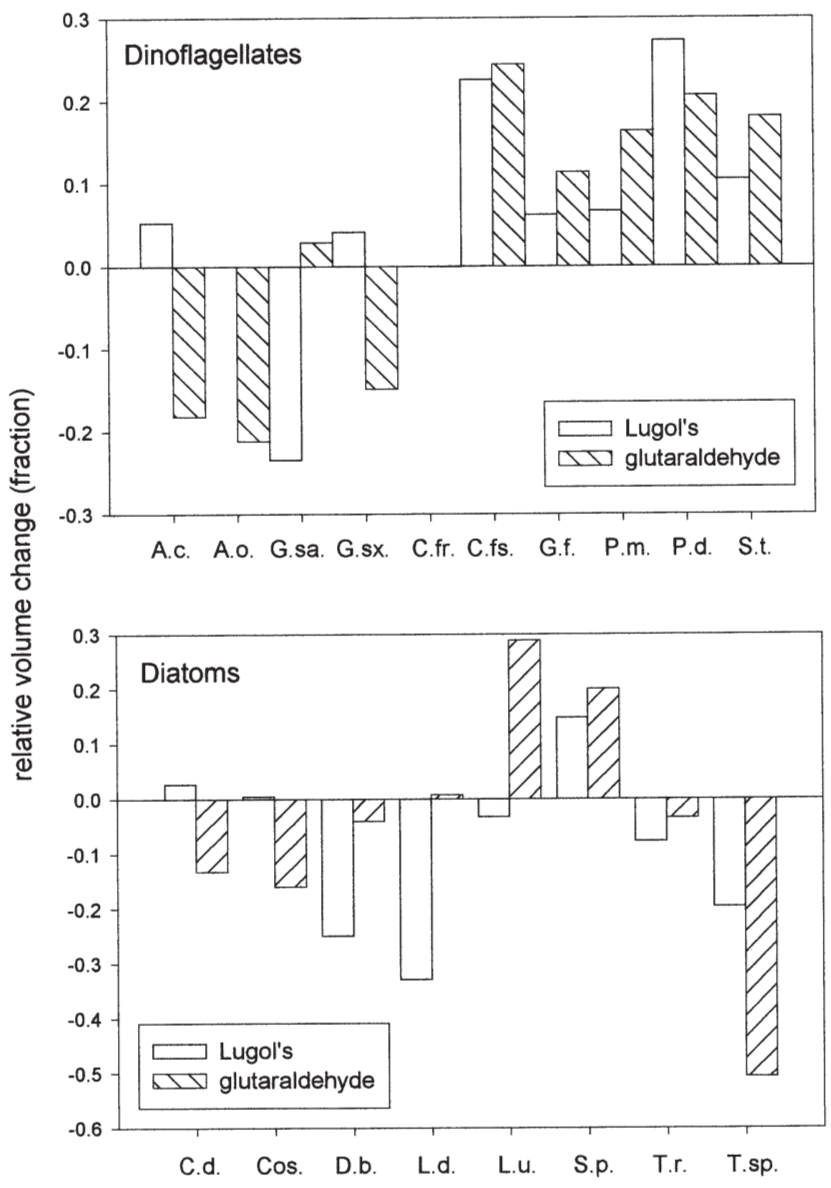

Fig. 1. Relative volume change of diatom and dinoflagellate species fixed with Lugol's and glutaraldehyde in settled samples measured with light microscopy (Table 2). The 0 line refers to no change relative to live volume. Athecate dinoflagellates: A.c., Amphidinium carterae; A.o., A. operculatum; G.sa., Gymnodinium sanguineum; G.sx., G. simplex. Thecate dinoflagellates: C.fr., Ceratium furca; C.fs., C. fusus G.f., G. foliaceum; P.m., Prorocentrum micans; P.d., Protoperidinium depressum; S.t., Scrippsiella trochoidea. Diatoms: C.f., Chaetoceros didymus; Cos., Coscinodiscus sp.; D.b., Ditylum brightwellii; L.d., Leptocylindrus danicus; L.u., Lithodesmium undulatum; S.p., Stephanopyxis palmeriana; T.r., Thalassiosira rotula; T.sp., Thalassiosira sp.

to $5 \%$ swelling. Similarly, diatom cell volume changes ranged from $33 \%$ shrinkage to $28 \%$ swelling. The absence of a significant change in cell volume for athecate dinoflagellates and diatoms may only apply to the particular group of species included in this study. Consequently, fixation-induced artifacts may not necessarily be ignored for athecate dinoflagellates and diatoms.

Time dependence. The effect of storage time on fixation-induced cell volume changes was examined for several dinoflagellate and diatom species (Fig. 2). All dinoflagellates, except for Gymnodinium sanguineum, were measured over a period of 3 mo The dinoflagel- 

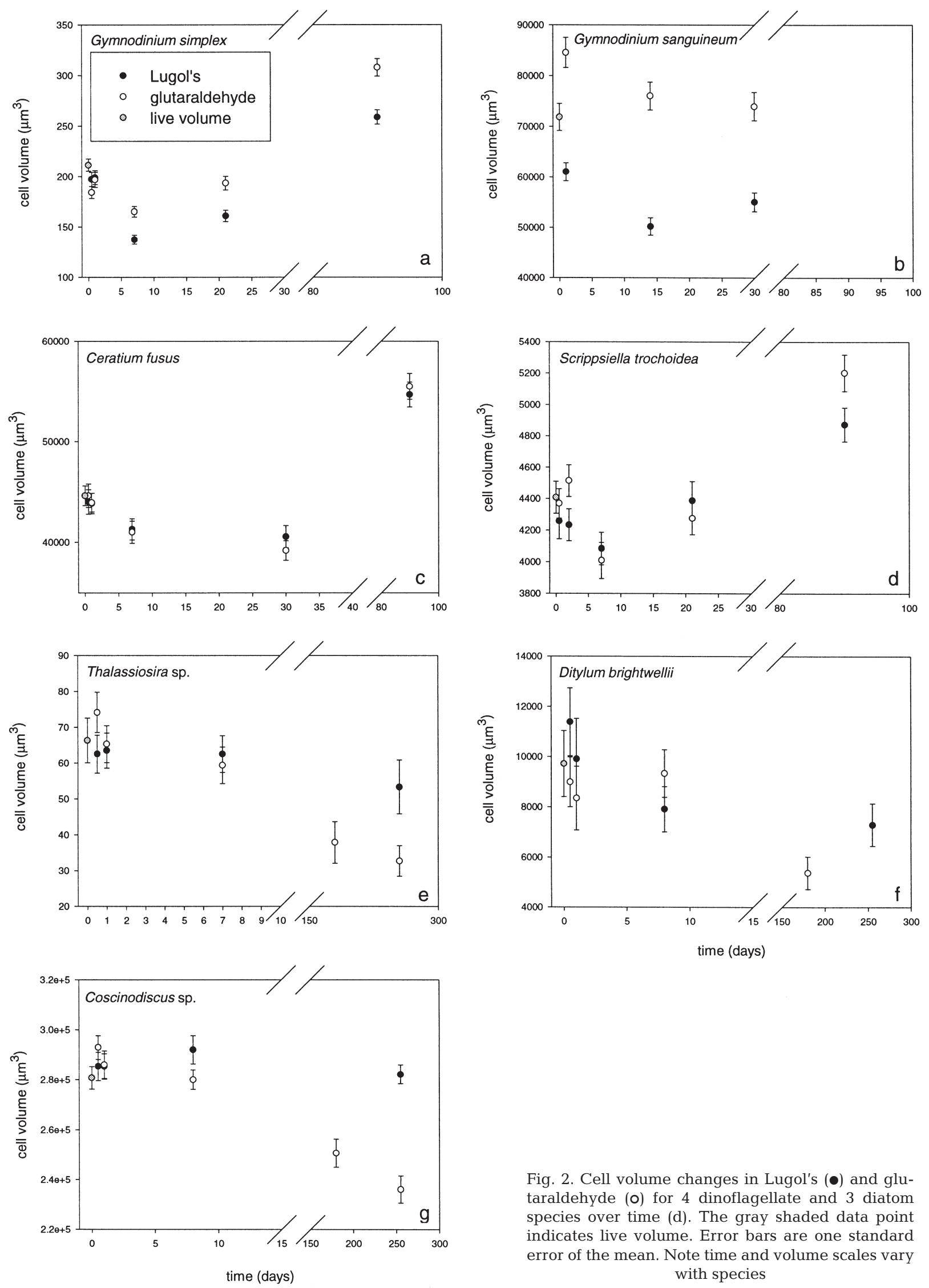

Fig. 2. Cell volume changes in Lugol's (•) and glutaraldehyde (o) for 4 dinoflagellate and 3 diatom species over time (d). The gray shaded data point indicates live volume. Error bars are one standard error of the mean. Note time and volume scales vary with species 


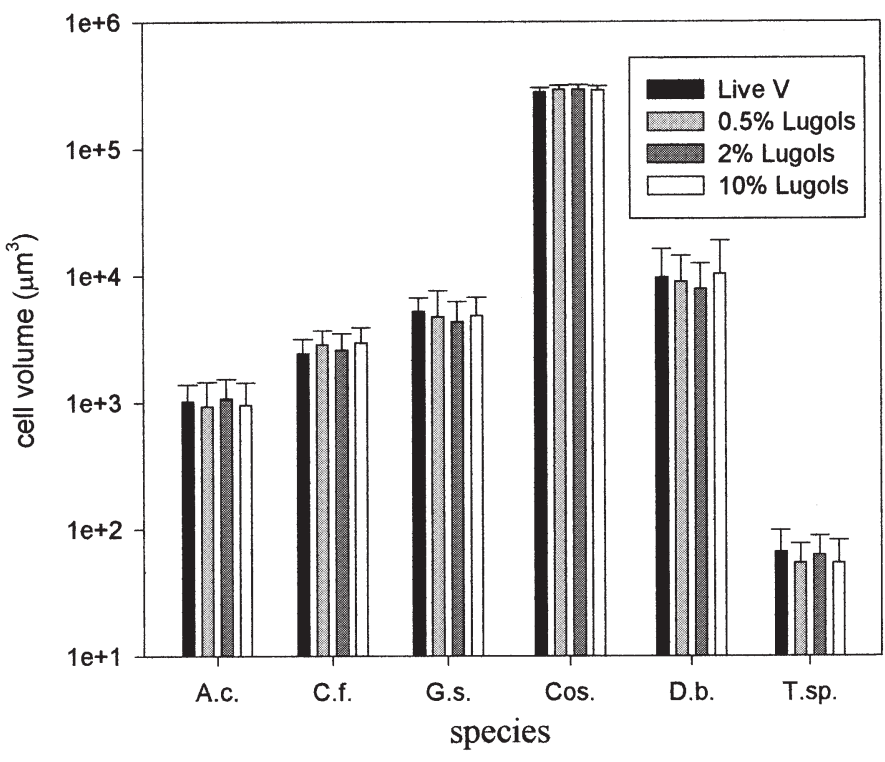

Fig. 3. Live and preserved cell volumes of 3 dinoflagellate and 3 diatom species. Error bars are $\pm 1 \mathrm{SD}$ of the mean. See Fig. 1 for species names affected by, for example, cell covering or fixative concentration.

The diatom species had different responses to prolonged fixation (Fig. 2e to g) than the dinoflagellates. During the first 3 to $24 \mathrm{~h}$ of fixation, diatom cell volume fluctuated but there was no significant difference between live and fixed measurements. Therefore, no correction would be necessary for diatoms measured within $1 \mathrm{~d}$ of fixation. After more than $1 \mathrm{wk}$ of fixation, mean cell volume for all 3 species shrank significantly. The cell volume changes in glutaraldehyde were about twice the change observed in Lugol's. For the smallest diatom, Thalassiosira sp., cell volume decreased over $50 \%$ after 8 mo of storage due to a change in linear dimensions of about $0.6 \mu \mathrm{m}$. Although this change resulted in a remarkable volume decrease, the difference in linear dimension approached the precision of the measurements. Fixation-induced changes in cell volume of very small cells may not be resolvable with this measurement method.

\section{Concentration dependence} (Fig. 2a to d). During the first day of fixation, cell volume varied considerably for all dinoflagellates. Initial shrinkage was followed by swelling or vice versa (Fig. 2a to d). After $3 \mathrm{mo}$, G. simplex volume had increased by $22 \%$ in Lugol's and $46 \%$ in glutaraldehyde. The 2 thecate species Ceratium fusus and Scrippsiella trochoidea shrank over the first month of fixation (up to $9 \%$ ) and after 3 mo had swelled by up to $24 \%$. The athecate dinoflagellates G. sanguineum and G. simplex showed significantly different reactions to the 2 fixative types $(\mathrm{p}<0.0001)$. Although no significant differences in response to Lugol's and glutaraldehyde fixation were found when all species were combined in the previous comparison, long-term storage in the 2 fixatives appears to induce differences in cell volume change. The data are insufficient to conclude whether this was a function of time alone or was also
Lugol's applied at 3 concentrations between 0.5 and $10 \%$ was observed to induce both swelling and shrinking in both dinoflagellates and diatoms. Only Coscinodiscus sp. was observed to swell and Thalassiosira sp. to shrink in response to all fixative concentrations (Fig. 3, p $<$ 0.0011). Fixation-induced cell volume changes of different concentrations of Lugol's were small compared to the inherent variability of cell volumes (Fig. 3). However, the time interval for this comparison was $1 \mathrm{~d}$ for dinoflagellates and $1 \mathrm{wk}$ for diatoms. The results from the time course experiment show that cell volume changes occur over longer periods than 1 wk. Therefore, this comparison should be conducted over longer periods to provide more conclusive evidence.

Table 4. Results of Model 1 least squares regression of $\log _{10}$ transformed cell volumes of live and fixed cells. Presented are the $y$-intercept (a) and the slope (b) of the regression equations, the standard error of the estimate (SE), the correlation coefficient ( $\mathrm{r}^{2}$ ) and the sample size (n). Live volume $(V)$ can be predicted from fixed volume $\left(\mu^{3}\right)$ based on the equation: $\log$ live $V=\log$ a + $\mathrm{b} \times \log$ fixed $V$. LM: light microscopy; EFM: epifluorescence microscopy

\begin{tabular}{|c|c|c|c|c|c|c|}
\hline Data & $\log a$ & $\mathrm{SE}$ & $\mathrm{b}$ & SE & $\mathrm{r}^{2}$ & $\mathrm{n}$ \\
\hline 1. Dinoflagellates and diatoms, LM $^{\mathrm{a}}$ & 0.162 & 0.043 & 0.960 & 0.011 & 0.996 & 34 \\
\hline 2. All dinoflagellates, EFM ${ }^{\mathrm{b}}$ & 0.692 & 0.138 & 0.867 & 0.036 & 0.980 & 14 \\
\hline 3. Thecate dinoflagellates, $\mathrm{LM}^{\mathrm{c}}$ & 0.025 & 0.045 & 0.980 & 0.010 & 0.999 & 11 \\
\hline \multicolumn{7}{|l|}{${ }^{\mathrm{a}}$ Eq. (1): all volume data from Table 2} \\
\hline \multicolumn{7}{|l|}{${ }^{\mathrm{b}} \mathrm{Eq}$. (2): all volume data from Table 3} \\
\hline${ }^{\mathrm{C}} \mathrm{Eq}$. (3): all thecate dinoflagellate vol & ta fro & & & & & \\
\hline
\end{tabular}




\section{Filtration and epifluorescence microscopy}

Fixation of dinoflagellates with $1 \%$ glutaraldehyde in combination with the filtration of cells onto slides and subsequent measurement by epifluorescence microscopy led to a significant shrinkage in cell volume ( $p=0.0002$, Table 3$)$. Preserved dinoflagellate cell volumes were on average $32 \%$ smaller than those of live cells (range -69 to $5 \%$ ). There was no significant difference between fixation-induced shrinkage in thecate and athecate species.

\section{Live volume predictions}

Regression analysis was used to examine if fixationinduced artifacts can be corrected for by predicting live cell volume from fixed cell volumes. No significant relationship was found between live and fixed cell volume of athecate dinoflagellates or diatoms. Significant regressions were determined for all dinoflagellate and diatom data in Table 2 combined (Eq. 1, Table 4), all data in Table 3 combined (Eq. 2, Table 4) and the regression of all thecate dinoflagellate data in Table 2 (Eq. 3, Table 4). The slopes of Eqs (1) \& (2) were significantly less than 1 , indicating that small cells shrink to a greater extent than large cells. Therefore, application of a constant shrinkage factor for all sizes, rather than the equations presented here, would lead to a systematic bias. The slope of Eq. (3) was not significantly different from $1(p=0.110)$. However, the exponent does influence the predicted live volume and should not be ignored.

\section{DISCUSSION}

The direction and magnitude of fixation-induced cell volume change in dinoflagellates and diatoms was not related to whether Lugol's or glutaraldehyde was used. Either fixation could induce swelling, shrinking or no change. Thecate dinoflagellates consistently swelled, whereas athecate dinoflagellates and diatoms both shrank and swelled in response to both fixatives. Significant differences in cell volume changes between the 2 different fixatives were only observed in a few species, especially after long-term storage. These results differ from previous studies on ciliates and heterotrophic nanoflagellates, which showed that Lugol's and glutaraldehyde appear to induce different trends in cell volume changes. Lugol's, with few exceptions, induces shrinking in marine and freshwater ciliates while glutaraldehyde can induce shrinking, swelling or no change (Putt \& Stoecker 1989, Jerome et al. 1993, Stoecker et al. 1994, Wiackowski et al. 1994). Similar observations have been made in 2 species of heterotrophic nanoflagellates (Choi \& Stoecker 1989) as well as in photosynthetic picoplankton and nanoflagellates (Booth 1987, Montagnes et al. 1994). These results suggest that dinoflagellates and diatoms have different responses to fixation with Lugol's and glutaraldehyde than other phylogenetic groups, especially ciliates. Thus, previously described correction factors for fixation-induced volume change should not be applied to dinoflagellates and diatoms. It is noteworthy that fixation-induced cell volume changes were observed in diatoms. It has long been assumed that diatoms are unaffected by fixation due to their silica frustule. The results agree with Montagnes et al. (1994), who observed cell volume changes in 3 diatom species after Lugol's fixation.

Time of storage was a factor with potentially significant effects on cell volume estimates (Fig. 2). Cell volume changes did not increase or decrease linearly during time of storage. The direction of cell volume change during short-term storage $(<1 \mathrm{wk})$ was quite variable for all species. During longer storage dinoflagellates and diatoms showed some consistent withingroup trends. In general, dinoflagellates shrank and then swelled (except for Gymnodinium sanguineum in glutaraldehyde) and diatoms shrank (except for Coscinodiscus sp. in Lugol's). Zinabu \& Bott (2000) also observed initial swelling followed by shrinkage in a flagellate and ciliate when fixed with formalin or a combination of formalin and Lugol's. A similar phenomenon was reported for freshwater ciliates stored for 2 mo (Wiackowski et al. 1994). The progressive swelling of dinoflagellates suggests that one potential cause of cell loss during storage may be due to timedependent bursting of cells. For diatoms, Lugol's induced smaller cell volume changes than glutaraldehyde during long term storage, and thus would be the preferable fixative to use. The effect of storage should be investigated further as differences in magnitude and sometimes even the direction of volume change were observed for some species between samples stored for periods of days versus months.

Fixative concentration was not a significant factor in the extent of cell volume change (Fig. 3). However, this comparison was based on measurements made after $1 \mathrm{~d}$ and $1 \mathrm{wk}$ of storage. Longer storage might show different results. Montagnes et al. (1994) also observed no consistent effect due to concentration of Lugol's when applied to various phytoplankton species. However, Stoecker et al. (1994) measured significantly lower ciliate cell volumes with 10 versus $5 \%$ Lugol's. Storage time and fixative concentration, along with other factors, probably interact to influence changes in cell volume and should be investigated simultaneously in future experiments. 


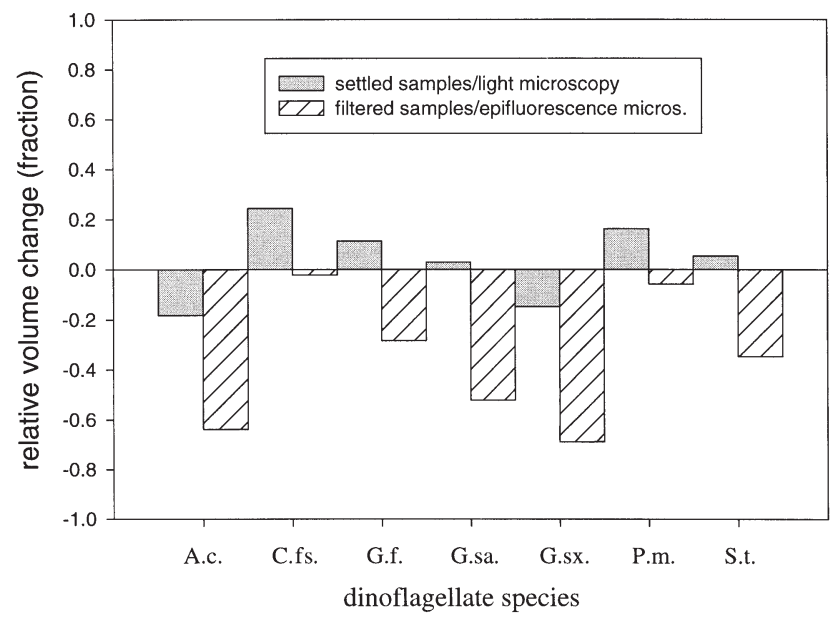

Fig. 4. Relative volume change of 7 dinoflagellate species fixed with glutaraldehyde in settled samples measured with light microscopy and filtered samples measured with epifluorescence microscopy. The 0 line refers to no change relative to live volume. See Fig. 1 for species definitions

The 2 methods of sample preparation of glutaraldehyde fixed cells (settling vs filtering) induced different cell volume changes in the same species (Fig. 4). Some species shrank and others swelled in settled samples measured with light microscopy while most species shrank when measured after filtration using epifluorescence microscopy. Booth (1987) examined cell diameter changes in Lugol's fixed and settled samples and glutaraldehyde fixed and filtered samples in pico- and nanoplankton and also observed both swelling and shrinking of similar magnitude. For the preservation of dinoflagellates and diatoms each method has particular advantages. The direction of the cell volume change would be difficult to predict, but the magnitude of change was generally lower in settled samples than in filtered samples. The filtration methods on the other hand, consistently induced shrinkage in most species. Although cell volume changes in filtered samples were greater in magnitude and more variable in extent than settled samples, the consistency in direction would be somewhat easier to account for. Several species of heterotrophic dinoflagellates were included in this study (Bernardinium sp., Oxyrrhis marina, Protoperidinium concicum, $P$. depressum, P. pellucidum). It appears that heterotrophic species, as a group did not show a different response than autotrophic species to both preparation methods.

Fixation-induced cell volume changes can have various ramifications but deserve particular attention due to their fundamental importance to $\mathrm{C}$ biomass estimates. To explore the quantitative importance of fixation on biomass estimates, predictions based on empirical live and fixed volumes for dinoflagellates and diatoms from this study were compared. Furthermore, the equations from Table 4 were applied to fixed cell volumes in order to determine if their use would improve $\mathrm{C}$ biomass estimates. All predictions of cellular $\mathrm{C}$ content are based on the $\mathrm{C}$ to volume conversion equations in Menden-Deuer \& Lessard (2000).

When data for all species measured with light microscopy (Table 2) were combined, cellular C content predictions based on fixed cell volumes were, on average, not different from estimates based on actual live volumes. However, the estimates for individual species ranged from a $44 \%$ underestimate to a $23 \%$ overestimate. This broad range was only slightly reduced (range -33 to $20 \%$ ) when C content estimates were based on predicted live volumes rather than fixed volumes (Eq. 1, Table 4). For the epifluorescence method, using fixed cell volume to determine $\mathrm{C}$ content of dinoflagellates led to an average underestimate of $26 \%$ (range -59 to $3 \%$ ). Application of the correction equation to predict live volume (Eq. 2, Table 4) improved average $\mathrm{C}$ content predictions, which was only $2 \%$ higher than was estimated using live volumes with a range from -35 to $45 \%$. A broader range of estimates ( -70 to $30 \%$ ) was observed when the correction factor of Montagnes et al. (1994, live volume $=1.33 \times$ fixed volume) was applied to predict live volume. For thecate dinoflagellates, cellular $\mathrm{C}$ content estimates were, on average, improved by using predicted live volumes (Eq. 3, Table 4) rather than fixed cell volumes. While fixed cell volumes led to an average $12 \%$ (0 to $22 \%$ ) overestimate of cellular $\mathrm{C}$ content, there was no difference (range -11 to $12 \%$ ) between cellular $\mathrm{C}$ based on predicted or empirically determined live cell volumes. C biomass predictions based on live versus fixed volumes for athecate dinoflagellates and diatoms as separate groups (Table 2) only differed about $10 \%$. Considering the large error associated with volume measurements, this appears to be an acceptable deviation. Application of the conversion equations (Table 4) improved average $\mathrm{C}$ content estimates for mixed plankton samples containing several species. If field samples were dominated by only a few species, such as in bloom situations, the bias of the estimate would be largely dependent on the cell volume response to fixation of that particular species. Furthermore, for all presented conversion equations the ranges of the estimates remained large since all treatments induced considerable changes in estimated cellular $\mathrm{C}$ content of individual species.

In conclusion, there are no simple approaches to correct for fixation-induced cell volume changes in individual species of dinoflagellates or diatoms. These results agree with previous studies, that preservation induces highly variable, species-specific effects (e.g. Pfister et al. 1999). Therefore, the selection of appro- 
priate corrections (if available) will be strongly case dependent. This species-specificity may be a function of factors such as organism physiology or growth stage (Jerome et al. 1993, Wiackowski et al. 1994). Many of these potential factors would be uncontrollable or unknowable in field samples. To improve volume and thus biomass estimates from fixed samples, it appears most important to quantify the direction and maximum extent of potential cell volume changes for important species. For both dinoflagellates and diatoms, preservation was observed to induce large changes in cell volume of individual species which can significantly affect derived variables such as specific metabolic rates and carbon biomass estimates for those species. The conversion equations presented here can inprove biomass estimates for some groups. Furthermore, fixation induced cell volume changes appear to be a negligible factor in estimates for mixed samples containing many species.

Acknowledgements. This research was supported by NSF grants OCE 94034226 and OPP 9315027 to E.J.L. Support for SMD was provided by Deutscher Akademischer Austausch Dienst (DAAD). Field isolates were made from plankton samples provided by Rita A. Horner obtained with support from NOAA Saltonstall-Kennedy Grant NA66FD0113 and NA86 FD0393 to Karl Banse. We thank E. Virgina Armbrust and Tatiana A. Rynearson for the provision of diatom cultures and Michael S. Foy for support in the lab. Rita A. Horner is gratefully acknowledged for her generous advice throughout the project. David Montagnes kindly provided recommendations on the manuscript and analysis. Comments from Dian Gifford and 2 anonymous reviewers improved this manuscript. S.M.D appreciates the support and advice generously provided by Danny Grünbaum.

\section{LITERATURE CITED}

Booth BC (1987) The use of autofluorescence for analyzing oceanic phytoplankton communities. Bot Mar 30: 101-108

Choi JW, Stoecker DK (1989) Effects of fixation on cell volume of marine planktonic protozoa. Appl Enivron Microbiol 55:1761-1765

Guillard RRL (1975) Culture of phytoplankton for feeding marine invertebrates. In: Smith WL, Chanley MH (eds) Culture of marine invertebrate animals. Plenum Press, New York

Jerome CA, Montagnes DJS, Taylor FJR (1993) The effect of the quantitative protargol stain (QPS) and Lugol's and

Editorial responsibility: Diane Stoecker (Contributing Editor), Cambridge, Maryland, USA
Bouin's fixatives on cell size: a more accurate estimate of ciliate biomass. J Eukaryot Microbiol 40:254-259

Leakey RJG, Burkhill PK, Sleigh MA (1994) A comparison of fixatives for the estimation of abundance and biovolume of marine planktonic ciliate populations. J Plankton Res 16: 375-389

Lessard EJ, Murell MC (1996) Distribution, abundance and size composition of heterotrophic dinoflagellates and ciliates in the Sargasso Sea near Bermuda. Deep-Sea Res 43: 1045-1065

Menden-Deuer S, Lessard EJ (2000) C to volume relationships for dinoflagellates, diatoms and other protist plankton. Limnol Oceanogr 45:569-579

Montagnes DJS, Berges DA, Harrison PA, Taylor FJR (1994) Estimating $\mathrm{C}$, nitrogen, protein and chlorophyll a from volume in marine phytoplankton. Limnol Oceanogr 39: 1044-1060

Mullin MM, Sloan PR, Eppley RW (1966) Relationship between $\mathrm{C}$ content, cell volume and area in phytoplankton. Limnol Oceanogr 11:307-311

Parsons TR, Stephens K, Strickland JDH (1961) On the chemical composition of eleven species of marine phytoplankters. J Fish Res Board Can 18:1001-1016

Pfister G, Sonntag B, Posch T (1999) Comparison of a direct live count and improved quantitative protargol stain (QPS) in determining abundance and cell volumes of pelagic freshwater protozoa. Aquat Microb Ecol 18:95-103

Putt M, Stoecker DK (1989) An experimentally determined C: volume ratio for marine 'oligotrichous' ciliates from estuarine and coastal waters. Limnol Oceanogr 34:1097-1103

Roff JC, Hopcroft RR (1986) High precision microcomputer based measuring system for ecological research. Can J Fish Aquat Sci 43:2044-2048

Stoecker DK, Gifford DJ, Putt M (1994) Preservation of marine planktonic ciliates: losses and cell shrinkage during fixation. Mar Ecol Prog Ser 110:293-299

Strathmann RR (1967) Estimating the organic C content of phytoplankton from cell volume or plasma volume. Limnol Oceanogr 12:411-418

Throndsen J (1978) Preservation and storage. In: Sournia A (ed) Phytoplankton manual. UNESCO, Paris, p 69-74

Verity PG, Langdon C (1984) Relationships between lorica volume, C, nitrogen, and ATP content of tintinnids in Narragansett Bay. J Plankton Res 66:859-868

Verity PG, Robertson CY, Tronzo CR, Andrews MG, Nelson JR, Sieracki ME (1992) Relationship between cell volume and $\mathrm{C}$ and nitrogen content of marine photosynthetic nanoplankton. Limnol Oceanogr 37:1434-1446

Wiackowski K, Doniec A, Fyda J (1994) An empirical study of the effect of fixation on ciliate cell volume. Mar Microb Food Webs 8:59-69

Zar JH (1996) Biostatistical analysis. Simon \& Schuster, Prentice Hall, Upper Saddle river, NJ

Zinabu GM, Bott TL (2000) The effects of formalin and Lugol's iodine solution on protozoal cell volume. Limnologica 30 : $59-63$

Submitted: October 24, 2000; Accepted: April 13, 2001

Proofs received from author(s): October 9, 2001 
